ENTREPRENEURSHIP AND SUSTAINABILITY ISSUES

ISSN 2345-0282 (online) http://jssidoi.org/jesi/

2019 Volume 7 Number (September)

http://doi.org/10.9770/jesi.2019.7.1(4)

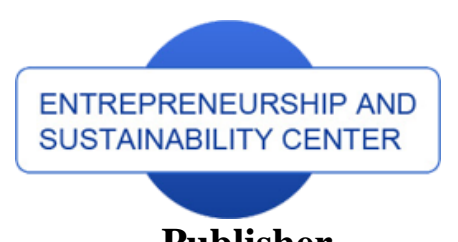

Publisher

http://jssidoi.org/esc/home

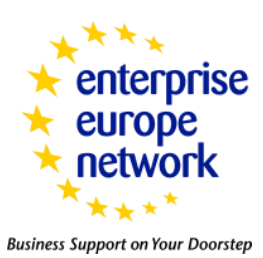

CASPA

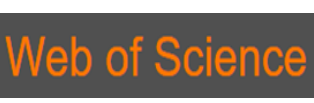

1) Clarivate

\title{
MULTIFACTOR ON MACROECONOMIC FUNDAMENTALS TO EXPLAIN THE BEHAVIOR OF SECTORAL INDICES IN THE INDONESIAN STOCK EXCHANGE
}

\author{
David Kaluge \\ Faculty of Economics, Brawijaya University, Malang, Jawa Timur 65145, Indonesia, Indonesia \\ E-mail: Davidk@ub.ac.id
}

Received 14 March 2019; accepted 10 July 2019; published 30 September 2019

\begin{abstract}
The purpose of this study is to investigate the impact of macro-fundamentals using factor approach on sectoral indices in the Indonesian Stock Exchange. This study uses monthly data on the returns of sectoral indices and uses Seemingly Unrelated Regression (SUR) analysis with a multifactor model. The results show that macro-economic variables can be classified into 2 common factors; Monetary Macro Factor (MMF) and Real Macro Factor (RMF). These factors have varying effects on different sectoral indices. Due to differences in the characteristics embodied in each sector, sectors then respond differently towards the change in macroeconomic conditions in Indonesia. The MMF is dominated by variables such as BI Rate, inflation, and exchange rates, while the MRF is influenced by other variables such as foreign exchange reserves, exports, and Indonesian crude oil prices. The MMF negatively affects indexes such as basic industry and chemical, consumer goods, infrastructure, manufacturing, mining, miscellaneous industries and property and trade, while the RMF has negative effect on the mining sector. By applying regression and Principal Components approaches, the model provides higher predictive power for the price behavior in each sector. This study found that the real sector is as important as the financial sector in influencing the capital market. This demonstrates a strong connection between the real and the financial. It also shows that the Indonesian capital market is dominantly controlled by investors rather than speculators. This is of particular importance for researchers who may be considering conducting a comparison of multifactor models and other methods such as CAPM and the Five Factor Model of Fama and French.
\end{abstract}

Keywords: macroeconomic; sectoral indices; macro-fundamental; factor approach; multifactor; model of Fama and French

Reference to this paper should be made as follows: Kaluge, D. 2019. Multifactor on macroeconomic fundamentals to explain the behavior of sectoral indices in the Indonesian stock exchange, Entrepreneurship and Sustainability Issues 7(1): 44-51.

http://doi.org/10.9770/jesi.2019.7.1(4)

JEL Classifications: G11, E44

\section{Introduction}

Macro-economics has a complicated impact on capital market. Abundantly macro variables have both direct or indirect effects on the capital market any given country. This impact can be investigated in terms of the change in returns (Angelidis et al. 2015; Aissia 2016, Bouri et al. 2016; Masood et al. 2019). Changes in returns is one of the primary concern of investors. In the midst of uncertain economic conditions, investors are likely to seek to 


\section{ENTREPRENEURSHIP AND SUSTAINABILITY ISSUES}

ISSN 2345-0282 (online) http://jssidoi.org/jesi/

2019 Volume 6 Number 4 (June)

http://doi.org/10.9770/jesi.2019.6.4(..)

secure the potential of their assets, and consider how to take advantage of their assets in order to remain valuable for the long term (Hung et al. 2014, Bouri 2015, Couch and Wu 2016). One kind of investment is trading in the capital market. Capital markets have an important role in the economy such as being a source of funding for businesses and for investment. People can invest in available financial instruments such as stocks, bonds and mutual funds. This allows the public to put its own funds into corporations based on the benefits and risks of different instruments.

It is generally accepted that macroeconomic conditions and the performance of capital markets have a strong relationship. Capital markets can be used to describe macro-economic conditions as they have an effect on investment value. In 2008, during the global financial crisis, the Indonesian economy was weakened by high inflation rates at $11 \%$, followed by the weakening of capital market conditions as described by JCI (Jakarta Composite Index) to a value of 1,355 points. In 2009, after the crisis, the economic conditions in Indonesia improved, followed by an increase in the JCI (Jakarta Composite Index). This phenomenon shows how macroeconomic conditions relate to capital markets.

In a Top-Down Portfolio approach in an investment decision, it is not only macroeconomic conditions, but the condition of sectors that is of concern. In a sectoral analysis, investors can compare the performance of various sectors, in order to know which sectors have good prospects for investment. There are 10 sectors in the Indonesian stock market that can be used for investment purposes: agriculture, mining, basic industry, miscellaneous industries, consumer goods, property, infrastructure, finance, trade and services, and manufacturing. After conducting an industry analysis, investors can use that information as a strategy to choose which sectors will be included in the portfolio to be formed. The macroeconomic condition and the condition of each sector inside are interlinked and interdependent on one another; both can affect the performance of a company. A company's performance can also affect the price of stocks and of various sectors.

Research on the effect of macroeconomic factors on sectoral indices has been investigated by Hasan et al. (2015) to determine the effect of macroeconomic factors such as GDP growth, the growth of money supply, inflation and interest rates of index return of 10 sectors in Bangladesh. The results of this research show that all of the macroeconomic variables investigated have an affect on the financial sector but not the real one. This means that macroeconomic variables do not have an affect on the investment sector, engineering sector, garment, paper and production, services, insurance and miscellaneous industries. Further, inflation and interest rates have an affect on the food sector and the sector of medicine and chemistry (Bekiros and Gupta 2015).

Abnormal returns often occur in the stock market and are very important for investment purposes. Abnormal returns occur due to the delivery of the information that causes market anomalies. Based on the random walk theory, stock prices move randomly and in an unpredictable manner. In an efficient market, the information disseminated by the market will respond quickly and rationally, so it is possible that the emergence of anomalies will result in abnormal returns. In an efficient market however, there is no "over information", because the market price is formed based on all the information. In an efficient market, the seasonal pattern of returns that can be predicted by the investor should not occur; this is against the empirical theory of efficient markets. that states "no one can beat the market" (Tandelilin 2001: 111). The conditions that cannot be predicted with any paradigm or empirical theory in the stock market are known as market anomalies. In other words, a market anomaly is a symptom of irregularities or inconsistencies in the capital market hypothesis. This theory does not apply to the real sector. Therefore, it seems that the real and the financial sectors are very dissimilar (Apergis, N, 2015). This encourages research on how capital market price behavior is related to both sectors. 


\section{ENTREPRENEURSHIP AND SUSTAINABILITY ISSUES}

ISSN 2345-0282 (online) http://jssidoi.org/jesi/

2019 Volume 6 Number 4 (June)

http://doi.org/10.9770/jesi.2019.6.4(..)

\section{Literature Review}

Capital markets are a market for a variety of long-term financial instruments that can be traded, either in the form of debt or equity capital (Husnan, 2003: 3). Capital is an important element in the production process. It is the accumulation of net investment, while investment is a commitment to sacrifice current consumption to increase consumption in the future (Tandelilin, 2010). Investment can be associated with save funds on real assets such as land, gold, houses and other real assets. Alternatively, it can take the form of financial assets such as deposits, stocks, bonds, and other securities. Stock is one type of investment instrument in capital markets. Investment in stocks is more advantageous compared to other instruments. The Indonesian capital market is growing each year, supported heavily by foreign investors due to the long term prosperity outlook of the Indonesian market (Aissia, D. B., 2016).

Before investing in any stock market, investor must conduct an analysis of the stock to obtain much information that will be used for their investment. Technical and fundamental analyses are used in this process. Fundamental analysis involves various factors such as the performance of the company, and all related macroeconomic variables that arguably influence prices. It also covers very wide areas as well as small or micro areas, from international economic condition such as the global economic situation, regional or country perspectives or even sectoral perspectives, right up to the management of a firm and its business conditions as shown by various financial ratios. At this stage, investors see macroeconomic conditions and the condition of the capital market as a whole and apply it in a Top Down strategy for investment decisions when selecting country for investment. Investors also conduct thorough analysis to determine which sectors and firms provide the best investment options. According to Tandelilin (2001), a company's prospects are highly dependent on the economy as a whole, hence, in stock valuation analysis, investors should pay close attention to macro variables that may affect the company's ability to generate profits. Macroeconomics may also affect the daily activities of the company, and the impact of this will have an overall affect on the performance of each company. Similarly, the economic conditions of each sector may influence the performance of the firms within each sector. Overall, these factors influence the sectoral indices and the JCI.

Interest rates are an important macro-economic variable affecting capital markets. High interest rates may reduce the present value of future cash flows, ultimately decreasing the attractiveness of investment. Higher the interest rate, in this case BI rate as the benchmark of interest rates, may lead investors to move their funds to invest in savings accounts or deposits. An increase of the BI Rate level influences the bank interest rates, and in particular deposits may increase, which will influence investors to invest in banks rather than in the stock market.

Foreign exchange reserves may also affect the stock price index. Foreign exchange reserves is the measurement of a country's level of income. If a country's foreign exchange reserve is high, the income received by these countries is also high. Foreign exchange reserves are closely related to the balance of payments. When the balance of payment is in surplus, this will be a positive sentiment for investors. Investors are keen to invest in the capital market because the economic conditions of capital markets are typically stable. Exports of certain sectors in an economy may affect the stock price of that sector. Thus, the balance of trade as well as the balance of payment have an affect on the capital market. When there is a trade balance deficit, it becomes a negative signal for investors and vice versa. When the amount of exports increases, this will be positive sentiment for investors.

Indonesia's crude oil price, for instance, may affect the stock price index. Crude oil is one of the sub-sectors of the mining and mineral sector. When crude oil prices increase, the stock prices of the mining sector will increase. This will increase the stock prices in that sector and this will attract investors. Hence, the increase in crude oil prices is a positive sentiment for investors, in particular for mining stocks. 


\section{ENTREPRENEURSHIP AND SUSTAINABILITY ISSUES}

ISSN 2345-0282 (online) http://jssidoi.org/jesi/

2019 Volume 6 Number 4 (June)

http://doi.org/10.9770/jesi.2019.6.4(..)

In a fundamental approach, the inflation rate is of primary concern as this may negatively affect stock prices. Inflation is the result of investors becoming pessimistic about the ability of capital to generate profits in the future. Inflation will cause a decrease in the profitability of companies, which will also have a negative effect on stock demand, which necessarily causes a decline in stock price.

Exchange rates, theoretically, may also affect stock prices because the stronger or weaker a currency is, the greater effect it will have on investors' willingness to invest in that currency. The strengthening of Rupiah against US dollar, for example, is a positive signal for the Indonesian economy, and will likely lead to an increase in foreign investment in Indonesia. For developing countries such as Indonesia, when exchange rates continue to grow, this will reduce importation costs, particularly the cost of importing raw materials. This will cause a decrease in production costs and push profits up. This causes an increase in dividends.

Market anomalies are a technique or strategy that seems to contradict the phenomenon of efficient markets. Some examples of anomalies include: fundamental anomalies, calendar anomalies, momentum and overreaction anomalies and the anomaly of Initial Public Offerings (IPO anomalies). Calendar anomalies is one anomaly in the time series of anomalies because it creates abnormal returns in certain periods. Calendar anomalies include the weekend effect, the holiday effect, the monthly effect and others.

Pujiharjanto (2010) states that the monthly effect is one of the calendar anomalies that occurs due to the returns in one or several months being larger than in other months. The existence of a market anomaly in a stock market shows that the condition of stock markets are not completely efficient.

The theory of anomalies tends to be neglected in real or production sectors. With the exception of the agricultural sector, which mostly relies on climate, all others tend to be stable in production year long. It seems that the real sectors are more likely to be characterized by technical relationships, while financial capital markets are influenced by emotional and social relationships. Since each sector in an economy has different characteristics, their relationship with the real and financial sectors could be different. Some factors will be more aligned with the financial sectors while others will be more aligned to the real sector, or there may be a balance between the two.

\section{Method}

This research investigates the effect of macroeconomic factors to sectoral stock price indices in the Indonesian Stock Exchange, using monthly data from 2007 to 2017. The data type is secondary data obtained from the Indonesian Bank, Indonesian Stock Exchange, Indonesian Ministry of Trade, and Ministry of Energy and Human Resources. The variables in this research are the return of sectoral indices listed on the Indonesian Stock Exchange: agriculture, basic industry and chemical, consumer goods, finance, infrastructure, manufacturing, mining, miscellaneous industries, property, and trade as dependent variable. The independent variables of this study are the BI rate, foreign exchange reserves, exports, inflation, Indonesian crude oil prices, exchange rates, and dummy variable that describe month of the year as the independent variables.

The approach used in this study is a multifactor model which is a class of the APT theory. Thus, all variables should be classified into groups called factors, then an estimation is conducted on the dependent variables against the independent factors, and of the predetermined ones.

The methods and stages of analysis in this study, include: establishment of a factor with Principal Component Analysis (PCA), and Seemingly Unrelated Regression (SUR). Principal Component Analysis (PCA) is a technique used to make new variables, which is a linear combination of the original variables. This analysis is used to create a set of new variables, or variable components, or latent variables, or factors, replacing a number 
with the original variable. This research formed 6 independent variable (X) into 2 factors and 10 sectors into 1 factor $(\mathrm{Y})$ to be used as independent variables.

Seemingly Unrelated Regression (SUR) is a regression that consists of multiple regression equation (regression equation system). The SUR method is used when there is a correlation between the regression equations. SUR can be used if the error or residual between the different equations are correlated, or in other words there is a contemporaneous correlation between the components. The SUR test is applied across a 12 month period to determine the month of the year effect. The t-test is used to determine the significance of an independent variable affecting the dependent variables. The coefficient of determination is to see the ability of the independent variables to explain the behavior of the dependent variable.

\section{Result and Discussion}

\subsection{PCA and SUR}

The formation of factors using the Principal Component Analysis (PCA) resulted in the X's Factor-1 which is referred to Monetary Macro Factors (MMF), consisting of the BI rate, inflation, and exchange rates. While belonging to X's factor-2 is Real Macro Factor (RMF) referred to real factor, consisting of foreign exchange reserves, export, and Indonesian crude oil prices. In addition to the establishment of the independent factors (MMF and RMF), this study also formed dependent factors (FY). Formation of the Y factor (FY) includes the return of 10 sectors' indices. FY is the formation of a new variable to describe the return of the 10 sectors. Note that PCA is used as a stepping stone only in this analysis, thus the estimation is not attached.

This study uses Seemingly Unrelated Regression (SUR) because there is a correlation between the residual errors showing that equations in the model are correlated, or in other words there is a contemporaneous correlation between sectors. The result are as follows:

$$
\begin{aligned}
R_{\text {agri }}= & 1.70-1.58 M M F_{t}-2.60 R M F_{t}-3.77 D 1+5.94 F Y_{t-1} & R^{2}=0.86626 \\
& (1.59)(-1.28) \quad(-1.36) \quad(-1.02) \quad(2,05) * * & \\
R_{\text {basic }}= & 1.39-2.52 M M F_{t}-0,44 R M F_{t}+4.17 D 1+1.43 F Y_{t-1} & R^{2}=0.72336 \\
& (1.72) * * *(-2.68) *(-0.30) \quad(1.49) \quad(0,65) & \\
R_{\text {cons }}= & 1.77-2.18 M M F_{t}+0.48 R M F_{t}+2,41 D 1+1,45 F Y_{t-1} & R^{2}=0.76231 \\
& (3,29) *(-3,50) * \quad(0,50) \quad(1.30) \quad(0,99) & \\
R_{\text {fin }}= & 1.12-1.62 M M F_{t}-0,18 R M F_{t}+6,22 D 1+0,92 F Y_{t-1} & R^{2}=0.89626 \\
& (1.50)(-1.88) * * *(-0,14) \quad(2,41) * * \quad(0,45) 5 &
\end{aligned}
$$




$$
\begin{aligned}
& R_{\text {infrastr }}=0,24-1.43 M M F_{t}+0,09 R M F_{t}+5.72 D 1+0,79 F Y_{t-1} \quad R^{2}=0.82622 \\
& (0,39)(-2,01) * * \quad(0,08) \quad(2,70) *(0,47) \\
& R_{\text {Manuf }}=1.53-2.59 M M F_{t}-0,23 R M F_{t}+4,29 D 1+1,10 F Y_{t-1} \quad R^{2}=0.89911 \\
& (2,38) * *(-3,47) * *(-0,20) \quad(1.93) * *(0,63) \\
& R_{\text {mining }}=1.06-3,35 M M F_{t}-4,37 R M F_{t}+0,02 D 1+4,89 F Y_{t-1} \quad R^{2}=0.74626 \\
& (0,95)(-2,58) *(-2,20) * * \quad(0,00) \quad(1,61) \\
& R_{\text {Miscel }}=1.57-2,96 M M F_{t}-1,33 R M F_{t}+6,55 D 1+0.94 F Y_{t-1} \quad R^{2}=0.67826 \\
& (1.73) * * *(-2.81) *(-0,82) \quad(2,09) * *(0,38) \\
& R_{\text {property }}=1.52-2,22 M M F_{t}+1,23 R M F_{t}+4,99 D 1+1,68 F Y_{t-1} \quad R^{2}=0.84536 \\
& (1.67) * * *(-2,10) * *(0,76) \quad(1.58) \quad(0,68) \\
& R_{\text {trade }}=1.41-2,71 M M F_{t}+1,73 R M F_{t}+0.95 D 1+3,78 F Y_{t-1} \quad R^{2}=0.87426 \\
& (1.91) * * *(-3,17) *(1,32) \quad(0,37) \quad(1,89) * * *
\end{aligned}
$$

Notes: figures in parenthesis is t statistics

$* * *$ is significant at $1 \%$ level, $* *$ at $5 \%$ level, and $*$ at $10 \%$ level.

The above results show that MMF (consisting of BI Rate, inflation and exchange rates) negatively affect basic industries and the chemical, consumer goods, infrastructure, manufacturing, mining, miscellaneous industries, property, and trade sectors. While RMF, which consists of foreign exchange reserves, exports and Indonesian crude oil prices, negatively affects the mining sector. The effect of each variable can be determined by multiplying the coefficient of the factor and the responding factor loading. After obtaining the factors (using Principal Component Analysis), the estimation of the Seemingly Unrelated Regression is conducted. The movement of the return of each sector in the previous period $\left(\mathrm{FY}_{\mathrm{t}-1}\right)$ has a positive effect on the agricultural and trade sectors.

Sectors in the capital market that react significantly on the change in macro-monetary-factors (MMF) are the basic industry, consumption goods, financial, infrastructure, manufacture, mining, miscellaneous goods, property, and trade. The mining sector is the only sector to have a significant reaction to the change in the macro-real-factor (RMF).

Many sectors are affected auto-regressively such as agriculture and trade. These results show that the effect of autoregressive is all positive. This means that the change today is in line with what has occurred in previous periods. This represents the behavior of investors; if prices increased in the last period, investors are more likely to invest in the current period. Sectors that have seasonal behavior, which are represented by the variable D1 are the financial, infrastructure, manufacture, and miscellaneous goods sectors. 


\section{ENTREPRENEURSHIP AND SUSTAINABILITY ISSUES}

ISSN 2345-0282 (online) http://jssidoi.org/jesi/

2019 Volume 6 Number 4 (June)

http://doi.org/10.9770/jesi.2019.6.4(..)

Macroeconomic factors in terms of monetary (MMF) consisting of the BI Rate, inflation, exchange rates and more dominant sectoral indices. BI Rate, inflation and exchange rates have a negative effect on basic industry and the chemical, consumer goods, infrastructure, manufacturing, mining, miscellaneous industry, property and trade sectors. The higher the interest rate, the higher the inflation rate, and the weaker the currency, which all result in a fall in stock prices.

Macroeconomic factors in real terms (RMF) consists of foreign exchange reserves, exports and Indonesia's crude oil prices, and also has a negative affect on the mining sector. This supports the findings of Basci (2013), who states that export affects the stock price index. There are several reasons behind this; due to the different characteristics among different sectors, each sector will respond differently to variables in economic conditions. For the mining sector, the Indonesian Ministry of Energy and Resources has issued a regulation contained in Law No. 4 of 2009 on Mineral and Coal Mining Policy. This is one variable distorting the price of firms in the mining sector from the market trend. That regulation places a ban on the export of raw minerals or raw material mines abroad which creates a negative sentiment for investors. When Indonesian crude oil prices increase, this will decrease the index return in the mining sector as crude oil is a substitution for mineral and coal mines. Meanwhile, that policy also causes the price of mining and minerals to decrease, which causes a decline in stock prices of coal mineral subsectors and the mining sector.

\section{Conclusion}

Macro-economic conditions will affect the daily activities of a company which will affect stock prices and sectoral conditions in a capital market. The characteristics of each sector / industry are different and each sector will respond differently to varying economic conditions. Based on this research, the monetary macroeconomic factor (BI rate, inflation and exchange rates) negatively affects basic industry and chemical, consumer goods, infrastructure, manufacturing, mining, miscellaneous industry, property and trade sectors. The Real Macro Economic Factor (foreign exchange reserves, exports and Indonesian crude oil prices), on the other hand, have a negative effect on the mining sector. Monetary macroeconomic factor have a more dominant effect on sectoral indices, and monetary variables will a larger affect on the environment and the company's performance, which will have a profound affect the respective sectors.

Based on above results, the following suggestions should be considered: Investors must consider the results of macroeconomic analysis and sectoral analysis before investing in stock market. This can be used to determine which sectors present a viable investment option. This will also reduce or minimize the risk of loss in a given stock market. The government is expected to maintain macroeconomic conditions, particularly in terms of monetary factors, because this directly affects the company's performance and ability to remain stable in the capital market, which may also affect the performance of the capital market particularly with respect to sectoral indices. Governments must create policies to encourage the performance of the capital markets so that capital market conditions in Indonesia continue to grow.

\section{References}

Aissia, Dorsaf Ben. (2016). Home and foreign investor sentiment and the stock returns. The Quarterly Review of Economics and Finance, 59, 71-77. http://dx.doi.org/10.1016/j.qref.2015.06.009

Angelidis, Timotheos, Sakkas, Athanasios, \& Tessaromatis, Nikolaos. (2015). Stock market dispersion, the business cycle and expected factor returns. Journal of Banking \& Finance, 59, 265-279. http://dx.doi.org/10.1016/j.jbankfin.2015.04.025

Apergis, Nicholas. (2015). Policy risks, technological risks and stock returns: New evidence from the US stock market. Economic Modelling, 51, 359-365. http://dx.doi.org/10.1016/j.econmod.2015.08.021 


\section{ENTREPRENEURSHIP AND SUSTAINABILITY ISSUES}

ISSN 2345-0282 (online) http://jssidoi.org/jesi/

2019 Volume 6 Number 4 (June)

http://doi.org/10.9770/jesi.2019.6.4(..)

Basci, Esref Savas. (2015). Yield Spreads on Government Benchmark Bonds: Cross Country Evidence. Procedia Economics and Finance, 30, 57-67. http://dx.doi.org/10.1016/S2212-5671(15)01255-1

Bekiros, Stelios, \& Gupta, Rangan. (2015). Predicting stock returns and volatility using consumption-aggregate wealth ratios: A nonlinear approach. Economics Letters, 131, 83-85. http://dx.doi.org/10.1016/j.econlet.2015.03.019

Bouri, Elie, Awartani, Basel, \& Maghyereh, Aktham. (2016). Crude oil prices and sectoral stock returns in Jordan around the Arab uprisings of 2010. Energy Economics, 56, 205-214. http://dx.doi.org/10.1016/j.eneco.2016.03.021

Bouri, Elie. (2015). Return and volatility linkages between oil prices and the Lebanese stock market in crisis periods. Energy, 89, 365-371. http://dx.doi.org/10.1016/j.energy.2015.05.121

Couch, Robert, \& Wu, Wei. (2016). The fair value option for liabilities and stock returns during the financial crisis. The Quarterly Review of Economics and Finance, 59, 83-98. http://dx.doi.org/10.1016/j.qref.2015.06.002

Hasan, Mostafa Monzur, Hossain, Mahmud, Cheung, Adrian, \& Habib, Ahsan. (2015). Corporate life cycle and cost of equity capital. Journal of Contemporary Accounting \& Economics, 11(1), 46-60. http://dx.doi.org/10.1016/j.jcae.2014.12.002

Heriqbaldi, Unggul, Ismail, Munawar, Kaluge, David, \& Santoso, Dwi Budi. (2014). A Regime Switching Analysis Of Indonesia's Exchange Market Pressure. The Singapore Economic Review, 59(02), 1450013. http://dx.doi.org/10.1142/s0217590814500131

Hung, Chi-Hsiou D., Azad, A. S. M. Sohel, \& Fang, Victor. (2014). Determinants of stock returns: Factors or systematic co-moments? Crisis versus non-crisis periods. Journal of International Financial Markets, Institutions and Money, 31, 14-29.: http://dx.doi.org/10.1016/j.intfin.2014.03.005

Kaluge, David, \& Puspita, Wilujeng. (2015). Asymmetric Reaction towards Financial Shocks in ASEAN Countries. Procedia - Social and Behavioral Sciences, 211, 519-527. http://dx.doi.org/10.1016/j.sbspro.2015.11.069

Masood, O., Tvaronavičienè, M., Javaria, K. 2019. Impact of oil prices on stock return: evidence from G7 countries, Insights into Regional Development 1(2): 129-137. https://doi.org/10.9770/ird.2019.1.2(4)

Pujiharjanto, C.A. (2013). Efek Kalender Bulanan di Bursa Efek Indonesia: Bukti Empiris dan Implikasi. Buletin Ekonomi Moneter dan Perbankan, 8(3), 98.

Tandelilin, E. (2001). Analisis Investasi dan Manajemen Portofolio. Yogyakarta: BPFE.

David KALUGE is a lecturer at Faculty of Economic and Business, Brawijaya University of Indonesia. He got his Master degree in of Economic Development from ANU and PhD from UC Canberra, Hes works has attracted best research in financial economics, banking and monetary as well as banking for poor people

ORCID ID: orcid.org/0000-0002-3369-6759

Copyright (C) 2019 by author(s) and VsI Entrepreneurship and Sustainability Center

This work is licensed under the Creative Commons Attribution International License (CC BY).

http://creativecommons.org/licenses/by/4.0/

(c) (i) Open Access 